\title{
Merekonstruksi Epistemologi Ibrahim
}

\author{
Rudyard Kipling
}

The modern politician, Samuel P. Huntingthon has stated that at the age XXI will enter the calsh of civilization. In fact, not all of scientist agree with Huntingthon, for example John L. Esposito has declared that Islam is not the threat but it will become the dynamic challenge to solve civilization in the future. In this sense, the writer has optimistic that needed is to epistemology reconstruction. This is the main reasons and that of reference. Hence, the epistemology of Ibrahim should be an alternative.

Kata Kunci: epistemologi, global, saint, intelegensi, positivisme

T imur ya Timur Barat ya Barat, Keduanya tidak akan pernah ketemu, menurut $C$. A. Qodir, ${ }^{1}$ menegaskan bahwa unsur-unsur pembentukan peradaban Barat, amatlah berbeda dengan unsur-unsur pembentukan peradaban masyarakat Timur. Penulis, mengungkapkan realitas sosial (termuat pula pemikiran filosofis) di dunia dirinya, dan juga image umum di lingkungan masyarakatnya. Amat kecillah kemungkinannya kalau bukan mustahil, dalam pemikiran Kipling, untuk kedua-duanya melakukan satu interaksi apalagi menyatu sebuah pembentuk peradaban baru. Entah karena hal itu dipahami oleh manusia, sebagai satu kondisi yang bertolak belakang, atau hanya sebatas karena adanya perbedaan sumber pengembangannya saja. Tidaklah terungkap secara eksplisit. Hanya saja, nampaknya, bila kita melihat sejarah perkembangan peradaban manusia secara global ataupun sebatas melihat perkembangan sains built-in ilmu pengetahuan dan teknologi (paradigma sains), ada yang mensinyalir karena adanya akar perselisihan politik antara Barat dan Timur, yang berawal dari Perang Salib (menurut Kristen), atau Perang Sabil (menurut umat lslam). Akar politik inilah yang membuat Barat dan Timur kemudian berkembang secara terpisah-pisah."

Akar politik itu, tidaklah sekadar menyisakan "dendam-politik" antara Timur dan Barat yang menghasilkan jiwa kecurigaan antara keduanya, tetapi juga memisahkan paradigma pengembangan pemikiran di kedua belah pihak tersebut.

Dalam dunia pemikiran, perbedaan antara Barat dan Timur ini, nampaknya lebih banyak disebabkan karena adanya perbe-

${ }^{1}$ C. A. Qodir. Filsafat dan IImu Pengetahuan dalam Islam. YOB: Jakarta, 1991: 1

2 Lihat John L. Esposito, Bahaya Hijau: Kesalahpahaman Barat Terhadap Islam. Pustaka Pelajar : Yogyakarta: 1997 
daan sumber pengembangan ilmu pengetahuan itu sendiri. Sebuah contoh yang dikedepankan Qodir, adalah tentang pengembangan teori pengetahuan. Di masyarakat Islam, kehidupan manusia termasuk dalam hal ini adalah struktur pengetahuannya, tidaklah bisa dilepaskan dari dimensi sakralitas atau konsepsi yang Kudus. Aksi sosial, maupun juga intelektual, selalu diposisikan sebagai bagian dari refleksi spiritualitasnya yang mengakui keberadaannya yang kudus. Lain halnya dengan apa yang terjadi di lingkungan masyarakat Barat hari ini. Dalam pengembangan sains, mereka sekemampuannya mencoba menghindari nilai-nilai kekudusan atau minimalnya sebuah reaksi alam dalam pandangan hukum alamnya (natural of law, sunnatullah) mesti dipahami secara obyektif material karena "hukum alam itu sendiri", sehingga dalam implikasi sosialnya (praksis sosial) dari sains itu sendiri berbeda.

Bila kita perhatikan secara lebih kritis, maka kehidupan di masyarakat Barat mengalami aneka proses pengikisan eksistensi manusia (erosi eksistensial). Kita sebut saja dengan erosi-eksistensial, dengan makna bahwa eksistensi manusia dalam konteks pemahaman seperti ini, digerogoti oleh satu ideologi yang mengakibatkan kian mengering dan mendangkalnya eksistensi manusia. Bahkan, akibat erosi eksistensi ini, eksistensi manusia kian menyerupai benda (pembendaan). Situasi sosial seperti ini,oleh para sosiolog kontemporer disebutnya dengan proses reifikasi. Lebih spesifiknya, adanya proses reifikasi individual dan reifikasi sosial. Manusia secara individu, atau secara sosial (komunitas) dianggap sebagai benda yang dapat direkayasa ibarat mesin-mekanik yang bersifat baku, robotisme di zaman modern.
Janganlah heran, bila kemudian kita mencoba melirik dunia pendidikan, misalnya. Anak sekolah atau peserta didik hari ini, banyak dicekoki oleh pelajaran tanpa memperhatikan kemampuan unik individunya masing-masing. Otoriter dalam dunia politik sangat buruk utuk diterapkan untuk semua konteks. Dan apalagi, otoriterianisme dalam pendidikan amatlah sangat berbahaya. Praktik otoriterianisme politik pun dapat kita pahami sebagai praktik pandangan hidup yang memposisikan manusia sebagai benda yang bisa direkayasa oleh manusia yang lainnya secara mekanik. Padahal hukum sosial itu, tidaklah bersifat matematis. Di dalam situasi inilah adanya fenomena sosial "perekayasaan manusia oleh manusia secara in-manusiawi".

Ketika kita masih ada dalam era Heraclitos $^{3}$ kita masih berada pada eksistensi yang menyatu dengan alam. Manusia masih terikat pada alam, sebagai satu kesatuan yang terintegrasi. Manusia adalah built-in dengan alam. Manusia adalah anggota kosmos itu sendiri, kendatipun disadari bahwa manusia memiliki derajat yang berbeda dengan anggota kosmos yang lainnya. Totalitas kosmos itu ternyata tidaklah berlanjut. Pada era berikutnya, manusia dihentakkan oleh Plato yang menggunakan idea manusia. Kosmos yang menyeluruh, mulai menyempit pada persoalan idea manusia saja. Atau, dalam istilah lain, adanya perubahan pemikiran dari sistem kosmos (cosmoscentrisme) ke wujud formasi idea manusia sentris (antropocentrisme). Usulan ini, banyak diminati ole pemikir-pemikir sesudah Plato, bahkan ada juga yang mengembangkannya ke sisi yang lainnya.

${ }^{3}$ Roger Garaudy, Mencari Agama pada Abad XX: Wasiat Filsfat Roger Garaudy, Bulan Bintang: Jakarta 1986: 159 
Renaisance di abad pertengahan yang merupakan awal kebangkitan manusia Barat, berusaha melepaskan kungkungan alam, diantaranya, terhadap manusia. Manusia ingin mandiri dan mampu mengatur diri, lebih jauhnya mampu mengendalikan lingkungan. Dengan demikian, terjadilah pergeseran tersebut tadi, yaitu dari berpusat pada alam ke format berpusat pada manusia. Penyambutan ide Plato terasa jbarat gayung bersambut. Barat sebagai sebuah komu-nitas peradaban telah mampu mengangkat derajat manusia dari pengaruh alam (secara terpaksa) menuju peradaban yang memusat pada sumber kekuatan manusia itu sendiri. Dipadukan dengan idea Plato, maka manusia itu pun dikikis, dan dipreteli eksistensinya. Manusia, bukan lagi manusia yang utuh. Melainkan manusia dalam arti yang memiliki idea yang dianggap tangguh. Tidaklah heran jika Plato ini mengklasifikasikan manusia ke dalam tiga kelas. Kelas yang arif yang berhak memimpin negara dipegang oleh filosof, kemudian kelas pemberani jadi militer dan kelas pekerja untuk buruh. Pengkelasan ini, secara implisit memposisikan derajat nilai kemanusiaan. Singkatnya, hanya orang yang memiliki idea cerdas sajalah yang berhak mendapatkan posisi terhormat.

Ide sebagai simbol kekuatan manusia dan pembeda derajat antar manusia, ternyata tidaklah bertahan utuh. Karena di kurun berikutnya, Rene Descartes menyebutnya dengan istilah 'rasio'. Cogito ergo sum. Itulah pernyataan masyhur dari Descartes. Sampai di titik ini, ternyata manusia masih belum puas untuk mengikis eksistensi dirinya. ${ }^{4}$

Akar erosi-eksistensi ini, sudah ada sejak zaman Yunani. Kenali saja, misalnya, Aristoteles tokoh sentral di Yunani setelah Plato. Jika Plato mengagungkan manusia itu hanya dari sisi idea saja, maka Aristo- teles mencoba untuk melepaskan nilai seni dari dimensi keunggulan dan keutuhan kemanusiaan. Tindakan yang dilakukannya, yakni memposisikan nilai (baca: dimensi estetis dalam jiwa manusia) yang dianggapnya hanya sebatas 'tiruan' saja. Plato sendiri, sudah mampu melepaskan dimensi estetik manusia ini dari keutuhan pemikirannya dalam "Republik"-nya. Di kalangan pemikir modern kita temukan Frederic Hegel, yang menganggap seni bukan sebagai unsur pembentuk totalitas peradaban. Hegel, memposisikan seni. pada level yang rendah. Padahal bagi kita sekarang ini dapat melihat bahwa seni itu adalah unsur empiris dan realitas dalam peradaban manusia. Bahkan para antropolog sendiri, mengkategorisasikan seni sebagai salah satu dimensi universal dari kebudayaan yang ada di masyarakat.

Pada tahap berikutnya setelah seni dikeluarkan dari status strategis eksistensi manusia, kini akalpun mulai digoncang oleh "badai erosi" ini. August Comte, adalah pemikir Prancis yang mengumandangkan era ini.Teori Comte, melalui tiga tahap perkembangan pemikiran manusia, telah mampu mengikis (merampingkan) akal manusia ke lokus yang lebih sempit lagi. Teori Positivistik, ${ }^{5}$ inilah nama yang terkenal untuk mengenali pemikiran Comte itu. Pada teori ini ditegaskan bahwa perkembangan pemikiran manusia itu berkembang dari mitos ke mitologi, dan kini sampai pada tahap positivistik. Dua karakter berfikir yang pertama, telah banyak dan selailu diupayakan ditinggalkan. Akal manusia atau lebih

4 Rene Descartes, Risalah Tentang Metode, Jakarta: Gramedia, 1995 : 34

5 Informasi kritis tentang filsafat positivistik ini, dapat dibaca pada "Arti Perkembangan: Menurut Filsafat Positivistik August Comte", Koento Wibisono, UGM Pres, 1983 
luasnya pemikiran manusia, pernah dan biasa berfikir mistis dan metafisis. Bagi penganut positivistik, kajian terhadap realitas yang bersifat ilmìh itu, adalah jika mampu melepaskan diri dari tradisi mistis dan metafisis. Sedangkan 'akal mistis' dan akal metafisis (termasuk tadi 'akal estetis') sudah ditinggalkan. Herman Soewandi, menyebutnya bahwa filsafat positivistik ini telah mampu melakukan proses pengeringan dan pendangkalan. ${ }^{6}$

Kita kali ini, memang tidak bermaksud untuk menjelaskan hal tersebut tadi. Namun, sekedar eksplorasi pemahaman saja dan sekalian dengan memberikan catatan penutup pada epistemologi Ibrahim ini, kita akan coba untuk menganalisis kasus yang ada di hadapan kita sekarang ini. Dengan merinci dari awal, manusia telah dipisahkan dari alam, itulan antropo-centrisme. Manusia dianggap sebagai pintu realitas. Tetapi kemudian, diri manusia itu sendiri ternyata hanyalah akal yang diakuinya sebagai penyebab utama keterhormatannya manusia. Eksistensi manusia, ditentukan oleh kualitas aktual akal itu sendiri. Filosofi ini telah bergerak lagi untuk meninggalkan realitas biologis manusia secara utuh terhadap eksistensi akal saja. Lebih mengerikan lagi, ternyata akal itu sendiri tidaklah memiliki eksistensi yang utuh. Akal 'keterpahaman' atau teranggap sebagai satu senyawa. Totalitas akal, tergoyang. Kalau boleh kita sebut, akal estetis telah dipisahkan dari "Akal" (dengan A besar). Kemudian Descartes mengikis akal ke arah dimensi akal (dengan a kecil) atau cogito.? Konkretnya, Comte juga telah memisahkan "akal mistis" dan "akal metafisis' dari akal, dan kini yang diakuinya hanyalah 'akal positivistik'.Itulah realitas erosi eksistensial manusia, sehingga kini menjadi kering. Sampai dititik ini, akal positivistik ternyata menghadapi perpecahan lagi. Akal positivistik ditangani oleh pemikiran dualitas, empirism idealis atau deduktifdeduktif. Tarikan ke tahap ini, sudah lebih sempit lagi daripada sebelumnya. Artinya, bagi mereka kendatipun akal positivistik digunakan tetapi jika dibandingkan (kata penganut empirisme), maka positivistik idealisme tidaklah mampu menjelaskan realitas. Demikian pula komentar sebaliknya.

Pengeringan dan pendangkalan ini, dapat kita lihat pula dalam penggunaan indikator keilmiahan dilingkungannya. Bagi ilmuwan positivistik, terdapat beberapa karakteristik sebuah kajian ilmiah itu disebut ilmiah. Misalnya saja, berkarakter material istik empiris, ada wujudnya dan bisa teralami dialami atau dibuktikan oleh siapa saja.Karakter ini identik dengan tak berTuhan. Kedua, kuantitatif maksudnya yaitu bisa diukur oleh statistik. Sifat ini juga membendakan, sebab, kritik kasus psikologis tidaklah bisa diangkakan seperti halnya mengukur batu atau bata. Inipun adalah kekerdilannya filsafat positivistik. Setelah melihat hal tersebut tadi, kian terpuruk sajalah eksistensi manusia itu.

Situasi yang lain, kita pun dihadapkan pada idea pelepasan sains (akal positivistik) dari realitas sosial. Idea netralitas sains, adalah konsep kunci dalam pelepasan akal-positivistik (atau akal sains) dari realitas sosial. Ide netralitas sains ini,

${ }^{6}$ Herman Soewandi, Nalar, Kontemplasi dan Realitas, Bandung, 1996: 8-9

${ }^{7}$ Satu buku yang relevan untuk dibaca, guna memahami tentang Erosi eksistensi aka ini, dapat ditemukan misalnya pada buku trrasionalisme, karya S. Roesjen BPK: Jakarta, $1957: 11-12$. 
menghantarkan manusia-pengembang sains yang menganggap adanya "jarak" antara sains (aplikasi sains) dan nilai-nilai sosial. Kecenderungan berikutnya, sains akan berkembang ke arah gejala dehumanisasi kemanusiaan. Inipun, adalah ancaman dari sains yang sudah tererosi.

Setelah memahami hal-hal tersebut tadi, maka pengetahuan, bukanlah hanya mengalami desakralisasi, seperti yang disinyalir oleh C.A. Qodir dan Sayyed Hosen Nasser ${ }^{8}$ tetapi juga degradasi nilai yang lainnya. Deestetikasi pengetahuan, desosialisasi pengetahuan, dehumanisasi pengetahuan, demistikasi pengetahuan, bahkan masih banyak lagi istilah-istilah lain yang relevan untuk menamai sebuah gejala pengikisan eksistensi pengetahuan atau akal manusia itu sendiri sesuai dengan dimensidimensi akal yang dikikisnya.

Mentaffakuri hal-hal tersebut di atas, penulis merasa merinding menghadapinya. Kita seolah-olah berhadapan dengan sains yang "berparadigma kemarau", kering dari nilai-nilai dasar kemanusiaan. Sains kering dari spiritual. Sains kaku dalam etika, serakah, congkak, karena tidak humanis. Sains itu mengerikan. Sains yang seperti inilah yang penulis sebut dengan paradigma kemarau.

Dari realitas itu, maka wajar dan cukup beralasan, malahan itulah semestinya, muncul satu kerinduan untuk menemukan satu paradigma ilmu yang mampu menutupi, bahkan mengganti paradigma lama tadi. Manusia mengharapkan muncul sebuah paradigma sains yang mampu mengembangkan eksistensi manusia ke arah yang lebih baik daripada kondisi sekarang ini, atau istilah Epistemologi lbrahim ini, adalah manusia yang hanif sehingga diposisikan sebagai ahlul bait oleh Allah SWT, dan dianggapnya sebagai khalilu'l lah, dalam mengurusi dunia.
Untuk konteks masyarakat Barat, saat ini tengah menggandrungi teori intelegensi yang baru, yang mereka sebut dengan emosional intelegensi sebagai pembanding dari IQ (Intelegence Quotient) yang sudah banyak dikenal masyarakat luas. Muncunya EI (Emotional Intellegence) ini, kita lihat sebagai sebuah reaksi atas kekakuan dan ketidakberdayaan IQ dalam menjawab "realitas kecerdasan" manusia. IQ lebih kental dengan kuantitatifnya intelegensi manusia. Pengukuran-pengukuran secara kuantitatif banyak dilakukan oleh manusia, sehingga mereka mengkategorisir manusia menjadi kelas debil, imbesil, idjot, bodoh, cerdas dan genius. Kelas-kelas manusia berdasarkan kuantifikasi IQ itu ternyata tidak menjelaskan persoalan, karenanya ternyata emosional juga memiliki peran penting dalam mengembangkan "kecerdasan" manusia, sehingga mereka menyebutnya kecerdasan emosional. Melihat fenomena ini, kita tidak mesti buru-buru untuk mengganti paradigma IQ dengan $E Q$. Munculnya teori itu, bukan untuk mereduksi. Melainkan untuk menambah, suplementatif atas kekurangan-kekurangan $1 Q$ sebelumnya, yang banyak dipengaruhi oleh filsafat positivistik. Sebab, dalam pemahaman penulis sekarang, gajala itu adalah gejala penemuan ulang atau "mudiknya" eksistensi akal-emosi kepada akal, tempatnya semula. Bahkan dari itu, penulis juga menghipotesiskan perlunya 'pemudikan' akal etis," akal-estetis, akal-mistis, akal-metafisis

${ }^{a}$ Ibjd., Qodir hal. 5 - 6.

9 Penggunaan kata 'akal' ini, bisa dialihmaknakan ke kecerdasan, sehingga, kita dapat temukan pemahaman ini sebagai padanan dari kecerdasan emosional, kecerdasan spiritual dan lain sebagainya. Mengenai eksistensi kecerdasan-kecerdasan tersebut tadi, insya Allah akan kita temukan kesempatan essai yang lainnya, insya Allah. 
kepada akal, sehingga akal menjadi utuh kembali sebagaimana pemahaman kita di awal bahasan ini. Rekonstruksi, itulah yang perlu dilakukan, setelah akal menga-lami dekosntruksi-dimensi oleh para filosof dan pemikir sekuler.

Sementara menanti masyarakat ilmiah mengenali keberadaan 'intelegensi' yang lainnya (akal), maka izinkanlah penulis untuk sedikit memberikan catatan kritis tentang Epistemologi Ibrahim ini. ${ }^{10} \mathrm{Hal}$ ini, penulis lakukan dalam rangka mengisi kelangkaan referensj yang membahas masalah ini.Uraian-uraian di bawah ini, penulis posisikan sebagai refleksi penulis terhadap perjalanan essai yang telah kita kedepankan.

Akal-religius (intelegensi spiritual, al'aqlal-ilahiah, religious-intellegence). Inilah akal yang pertama, yang penulis ingin jelaskan. Untuk kondisi masyarakat yang termodernkan bahasannya, mungkin akan lebih mengenal bila menggunakan istilah religiusisme-intelegensia, sebagai sandingan dari kecerdasan yang lainnya, atau kita singkat dengan istilah $\mathrm{RQ}$ (analogi dengan IQ, EQ). Untuk konteks sekarang, kita jelaskan berdasarkan penggunaan kata 'akal religius' dengan makna yang sebanding. Maksudnya dari akal religius ini adalah sebuah fakultas akal yang menyadari akan keberadaannya yang kudus, sebagai satu kekuatan 'sempurna' di luar dirinya sendiri, bahkan di luar eksistensi alam. Keberadaan yang kudus, bagi akal religius, cukup sentral. Bahkan kalau dikaitkan dengan Epistemologi Ibrahim, pada khususnya, atau Epistemologi Islam pada umumnya, maka akal religiusme adalah diposisikan sebagai sumber utama dalam perkembangan dan pengembangan pemikiran muslim atau peradaban muslim secara keseluruhan. Penting pula penulis ungkapkan, bahwa akal religiusme itu dapat dipandang pada dua wujud. Wujud pertama, akal religiusme pemberian (al-'aqli al ilahi wahbiyyah). Fenomena hidayah atau petunjuk Allah SWT, merupakan konsep kunci (key concept) dalam memahamj realitas ini. Hidayatuddin, demikian salah satu jenis hidayah yang ada, adalah mutlak pemberian Allah SWT kepada hamba-Nya yang dikehendaki-Nya. Dengan kata lain, maka kata "hidayah" adalah cukup deskriptif (tabayyun) untuk menjelaskan keberadaannya akal religius pemberian ini. Ulama klasik, atau juga cendekiawan kontemporer, seringkali menyebutnya dengan istilah ilmu laduni. Pada etafe sejarah muslim awal, Rasulullah Muhammad Saw, tidaklah disebut memiliki ilmu laduni, melainkan memiliki wahyu. Wahyu itupun, kita kategorikan sebagai akal religius pemberian." Yang kedua, yaitu akal religius hasil usaha (al-a'ql al-ilahi kasbiyyah), atau akal religius yang didapat atas hasil usaha, atau kerja kita. Konteks Tarbiyyah, cukup relevan untuk menjadi contoh bagaimana menanamkan dan atau mengembangkan religiusisme peserta didik.Bila kita mencoba mencari pemahaman keberagamaan dengan menjadikan Al-Qur'an dan Sunnah sebagai informasi utama dalam pengambilan keputusan, dengan disadari dan didasari

${ }^{10}$ Sekali lagi, penulis ingin ungkap bahwa analisis tentang ragam kecerdasan ini, akan kita bahas secara singkatnya saja.

"Dalam pengertian sederhana, ilham atau inspirasi dapat dikategorikan sebagai salah satu fenomena akal-seligius atau wahyu (dalam ukuran tertentu). Tentang ilham atau inspirasi ini sangat dikenal di dunia barat, dan peranannya amat penting diakui oleh mereka khususnya dalam dunia sains atau pengetahuan. Dalam hal ini agama itulah yang disebut dengan wahyu . AFB Baines Hewutt, Mehdi Khorasani. Islam Rasional, Mizan: Bandung, 1989: 24 - 25 
oleh keyakinan akan nilai sucinya Al-Qur'an dan Sunnah.

Pemilahan seperti ini memang cukup artifisial. Namun secara teoritis hal demikian memang perlu dilakukan dalam rangka mempermudah pemahaman konsep-konsep yang akan terkait dengan persoalan tersebut di atas. Dalam praktiknya, atau dalam fenomena praktisnya, kedua jenis akal religius ini (terkadang) memiliki hubungan yang tidak bisa dipisahkan. Nilai interaktif antara keduanya, juga kadang-kadang muncul sebagai sebuah fenomena sosial keagamaan. Fenomena ini jugalah yang terjadi pada Ibrahim As, ketika dia mengatakan "tanpa petunjuk dari Tuhan" dirinya akan tersesat. Atau juga keyakinannya, terhadap apa yang diterimanya ketika tidur (mimpi mendapatkan perintah wahyu-dari Allah SWT untuk menyembelih anaknya, Isma'il As). Ada juga hadits Muhammad Rasulullah Saw, yang mengisyaratkan adanya jenis akal ini (jenis akal religius). Ketika datang seorang sahabat kepadanya, kemudian bertanya tentang cara mencangkok pohon kurma, Rasulullah Saw. menjawab bahwa 'urusan agama, Allah dan rasulNyalah yang menetapkan sementara kamu lebih tahu tentang urusan duniamu" antum a'lamu bi umuridunyakum, kalimat ini memberikan isyarat bahwa manusia di luar Rasulullah Saw, memiliki akal duniawi yang lebih bajk dibandingkan dengan dirinya, dan manusia di luar dirinya lebih proporsional dalam mengurusi urusan dunia, karena memang mereka memiliki akal-duniawi tersebut tadi. Sedangkan akal keagamaan, hanya Allah dan Rasul-Nya sajalah yang berhak untuk menentukannya. Nilai hanifiah pada diri Ibrahim As, adalah representatif konsep untuk menjelaskan kualitas akal termaksud ini.
Akal etis (EtQ) menunjukkan tentang kemampuan dan kesadaran aksi di lingkungan sosialnya. Manusia hidup di masyarakat. Di sini kita berhadapan dengan manusia, kepentingan manusia dan kebutuhan manusia yang lainnya. Setiap manusia memiliki motivasi dan hasrat hidup bahagia. Akal etis inilah yang aktif dan dinamis dalam mencermati persoalan. Dari akal etis ini, manusia mengharapkan hidup bahagia, senang, selamat, tenteram dan juga teratur. Dari akal ini pula, berkembangnya harga diri manusia (aktualisasi nilai kemanusiaan). Akal etis, dalam hal ini bisa juga disebut dengan akal sosial atau etika hidup. Apapun sumbernya, pada dasarnya manusia ingin hidup terafur dan saling menghormati, hidup berkeadilan, dan tidak mau saling eksploitasi antara satu dengan yang lainnya. Dari itu munculnya konsep HAM, Declarations of Human Right, atau Piagam Madinah.

Kesadaran penulis tentang ada dan perlunya menggunakan akal etis ini, adalah untuk menggantikan paradigma sains yang dikatakan netral. Netralitas sains itu telah membuahkan hasilnya yaitu adanya dehumanisasi peradaban. Oleh karena itu, akal etis perlu dikembangkan dalam rangka memperbaiki derajat peradaban itu sendiri. Jika terus menerus mengembangkan sains yang netral, maka bukan hal yang mustahil jika para ilmuwan atau manusia itu akan memiliki karakter pribadi yang tidak peka pada masalah-masalah sosial. Padahal kepekaan sosial itu adalah juga turut menentukan kesempurnaan kemanusiaannya seseorang dalam hidup di dunia ini, lebih-lebih di akherat. Untuk memenuhi kebutuhan tersebut, maka kesadarankesadaran etis dalam diri manusia, guna membekalinya hidup di masyarakat adalah amatlah strategis dengan cara mengembangkan akal-etis ini. 
Pada uraian kita di depan, kita juga menemukan bagaimana Ibrahim As, tetap memiliki kepekaan sosial, walaupun dia harus tegas dalam berdakwah. Ketika mendakwahi orang tuanya, yang musyrik, Ibrahim As menggunakan bahasa yang santun. Ketika ada Malaikat yang membawa berita dari Allah tentang datang azab kepada umat Nabi Luth, Ibrahim As pun masih juga menampakkan satu kepeduliannya kepada umat manusia tersebut. Pada diri Muhammad Saw pun, kita temukan hal serupa. Misalnya saja, ketika datang para Malaikat yang siap membantu Rasulullah Saw melawan orang kafir dengan mendatangkan azab, Rasulullah ternyata lebih baik mengambil untuk tidak mengazabnya, alasannya "Mereka belum paham tentang Islam", dan demikian pula ketika musuhnya ada yang sakit dan suka menyakiti Rasulullah Saw, ternyata Rasulullah Saw jugalah yang pertama menengok orang tersebut, padahal orang itu adalah orang yang suka meludahi Rasulullah Saw setiap pagi ketika pulang pagi setelah shalat subuh di mesjid. Inilah yang penulis sebut dengan akal etis. Secara sederhananya, akal etis ini perlu dikembangkan. Sebab bila hal ini terlupakan, maka manusia akan lebih kejam daripada binatang itu sendiri.

Akal-emosi (al'agl an-nafsiah, emotionalintellegence) juga penulis temukan pada Epistemologi lbrahim ini. Tampaknyajuga oukup penting untuk diperhatikan oleh kita semua. Kasus ini dapat kita telaah pada kasus Ibrahim merninta pembuktian pada Allah SWT dalam membuktikan diri-Nya sebagai Tuhan yang mampu menghidupkan dan mematikan. Permohonan itu dikabulkan Allah SWT. Eksperimen-religiusnyadilakukan dengan cara memisahkan (ada juga memotong-motong bagian-bagian tubuh) 4 ekor burung. Ketika itu, Ibrahim ditanya, "Apakah lbrahimbelumyakin?" jawabnya, adalah "Supaya tambah yakin".
Ungkapan inilah yang penulis sebut dengan ekspresi emosional ataujiwa manusia. Naluriah, itulah kesan pertama penulis ketika membaca ayat ini. Keinginan Ibrahim yang sudah yakin meminta bukti kepada Allah, dengan tujuan supaya "lebih yakin" dengan cara yang meyakinkan ini, adalah sangat alami dan wajar dimiliki oleh manusia, sekalipun dia adalah nabi dan rasul yang sudah memiliki keimanan yang tinggi. Ibrahim kerap kali, memiliki sikap seperti ini. ${ }^{12}$

Gelora iman yang ada dalam diri lbrahim As sudah tinggi, tetapi jiwa kemanusiaannya supaya "reugreug" masih ada, dan itulah yang penulis sebut dengan akal-emosi (atau akal kejiwaan). Kasus yang lainnya, lbrahim juga telah melakukan dialog dengan anaknya, Isma'il As ketika ada wahyu untuk menyembelihnya. lbrahim sudah yakin bahwa perintah yang datang dalam mimpi itu adalah wahyu. Tetapi, masih juga bertanya kepada Isma'il dalam pelaksa-naannya. Demikian pula ketika Ibrahim mendapat berita dari Malaikat bahwaAllah akan memberkati putra Ishaq dari Siti Sarah. Ketika mendapatkan informasi itupun, khususnya Sarah malahan balik 'memperta-nyakan' tentang kebenaran berita Malaikat tersebut tadi. Inipun adalah contoh-contoh kasus tentang akal-emosional yang aktual. Dengan kata lain pertanyaan atau pernya-taan Ibrahim dalam kasus-kasus tersebut bukanlah bermakna keraguan, melainkan sebagai sebuah ekspresi jiwa kemanu-siaan. ${ }^{13}$

- ${ }^{12}$ Perhatikanlah ayat berikut ini, "Dan ingatiah ketika Jbrahim berkata: 'Ya Tuhan, perlihatkanlah kepadaku bagaimana Engkau menghidupkan orang-orang mat". Allah berfirman, "Apakah kamu belum percaya?". Ibrahim menjawab, "Saya telah percaya, akan tetapi supaya bertambah tetap hati saya", QS 2: 260

${ }^{13}$ Lihat QS An'am : 84 atau Al-Maraghy jus $7: 107-109$ 
Ekspresi jiwa inj, sekarang mulai dilirik masyarakat modern sebagai bagian utama dalam mengembangkan kecerdasan manusia saat ini. Mereka mengenalinya dengan konsep emosional-intelegensi. Apapun namanya, hal ini perlu untuk diperhatikan oleh kita bersama.

Wujud yang berikut yang berkaitan dengan akal ini, dan khususnya yang suka disandingkan dengan akal emosional saat ini, yaitu akal-idrakiyyah dan akal hissiah, atau lebih singkatnya yaitu akal indrawi dan rasional. Bahkan, kalau kita melihat ayat 26- di surat al-Baqarah di atas, di sana ada korelasi 'akal' emosional dengan akalempirisme atau indrawiyah, dan pada posisi seperti ini jugalah nilai rasional lbrahim As berkembang dalam proses pencaharian nilai kemanusiaan di muka bumi ini. Akal ini, memiliki karakteristik eksak, atau manut pada sebuah aturan atau silogisme tertentu, apakah itu empirisme atau rasionalisme. Demikian pulalah yang pernah digunakan oleh Ibrahim As ketika menganalisis "ketuhanannya" bintang, bulan dan matahari. Komparasi model Tuhan yang pertama antara malam dan bintang yang terang. Kemudian antara bintang dan bulan yang lebih terang, terakhir yaitu antara bulan dan matahari yang lebih besar. Sifat keredupan adalah nuansa kualitatif, sedangkan sifat besar-kecil yang sifat geometris cenderung kuantitatif. Itulah karakteristik dari akal idrakiyyah dan hissiah ini. Dengan kata lain, rasio atau rasionalitas, juga digunakan dalam epistemologi ibrahim ini. Kita tidak bisa menghindari keberadaan hal ini. Tersebab, keberadaanya akal ini adalah riil dan empiris, tidak bisa kita tutup-tutupi. Subhanallah, sampai disini saja, kita telah menemukan Ibrahim sebagai figur kita untuk berfikir. Dengan kelengkapan yang dia miliki, dan dia gunakan, maka pantaslah kiranya lbrahim As itu disebut dengan khalilullah, atau hamba Allah yang hanif dan al-Mustafa (hamba pilihan). ${ }^{14}$

Kodifikasi figh Islam, bisa dijadikan contoh konkret bagaimana pengaruh pemikiran rasional dan empiris itu digunakan oleh masyarakat muslim masa lalu ataupun juga masa sekarang. Perkembangan awal sejarah muslim pun, telah banyak diwarnai oleh ulama muslim yang berrikir eksakta ini. Misalnya saja, kita mengenal Ibnu Sina dan Ibnu Rusyd dalam bidang kedokteran. Ada Al-Khawarizmi dan Al-Jabr dalam bidang matematika. Ada Al-Biruni dalam bidang Astronomi dan geografi. ${ }^{15}$ IImu-ilmu tersebut, perkembangannya sarat dengan aka!rasional dan empiris untuk pengembangannya. Kendatipun bukan berarti bahwa mereka mengembangkannya secara monodimensional (linearitas). Sebab,yang terakhir itu, adalah salah satu bencana akal manusia modern sekarang ini, yang hanya menggunakan akal dalam dimensi yang tunggal, sehingga kehilangan nilai akal yang seutuhnya.

Kasus persidangan Ibrahim oleh raja Namrud ketika dituduh merusak Tuhannya, adalah hal yang menarik untuk dianalisis oleh kita bersama. Sebelum sampai ke persidangan, lbrahim As melakukan satu mekanisme-operasional, yang secara "yuridis" adalah langkah-langkah yang konstitusional. Ibrahim As ingin mencari Tuhan yang berkuasa, maka ditanyalah satu persatu dari Tuhan-Tuhan yang ada ruang peribadatan Namrud tersebut tadi. Namun, karena tidak ada yang menjawab, maka dirusaklah Tuhan-Tuhan yang kecil itu, dan disisakan satu yang terbesarnya sambil

${ }^{14}$ QS. Al-An'am : $75-80$.

15 Ibid. C.A. Qodir, hal. 111 - 130 . juga dealektika Islam: alam Pikiran Islam. M.M. Sharif, Dipenegoro: Bandung, 1970, 43-124. 
dikalungi oleh kapak penghancurnya tadi. Data mekanisme operasional itu dijadikan dali untuk melawan Hujjah dari raja Namrud. Dan, alhamdulillah wa Suhanallah yang telah memberikan hidayah pada Ibrahim As, ternyata hujjah Ibrahim As yang secara rasional itu dapat dipahami oleh kita bersama mampu membungkam 'ideologi ketuhanannya' raja Namrud. Teknik Ibrahim As itulah yang penulis ingin sebut dengan teknik operasional yang strategis, dan itulah akal teknisnya manusia (teknik mungkin juga politis dan strategis). Nilai yang penting yang perlu untuk direnungkan oleh kita adalah urgensinya akal-teknik dalam kehidupan sehari-hari. ${ }^{16}$ Akal teknis ini dapat pula kitapahami sebagai potensi dari akal-kreatifnya Ibrahim As.

Pada kasus Ibrahim As itu, sebenarnya dia mampu mengalahkan Namrud dengan menggunakan akal-religiusnya (dalil naqli). Namun, yang terpenting adalah kesadaran kita dalam menghadapi realitas atau mustami (pendengar, siswa atau umat) yang memiliki kemampuan yang berbeda dengan kita.Inilah yang perlu untuk disadari. Nampaknya, "akal" masyarakat inilah yang dipahami oleh lbrahim As melalui kepekaannya akan kondisi dan situasi umatnya, termasuk juga tingkat pemahamannya sebagai realitas hidup, maka Ibrahim As menggunakan teknik pembuktian yang sangat praktis dalam menyadarkan tentang ketuhanannya Namrud. Walaupun gagal mentauhidkan Namrud, namun berhasil dalam menggagalkan hujjah ketuhanannya. Inilah titik penting yang perlu untuk dipelajari. Berdasarkan data empiris dan meterial, lbrahim dengan mudah mengatakan bahwa patung-patung yang tidak berdaya itu bukanlah Tuhan.

Problema akal teknis ini, amat berguna bagi kehidupan kita sekarang ini. Khususnya, jika akal-teknis ini diartikan - salah satu diantaranya - sebagai sebuah upaya manusia dengan cara efektif dan efisien dalam mencapai cita yang direncanakan. Sebuah pencapaian tujuan, jika tidak memperhatikan masalah seperti ini maka akan menghasilkan satu wacana kegiatan yang bersifat boros. Dalam ekonomi dikenal adanya konsep $h i g h$-cost economi, demikian pula dalam masalah sosial, ada high cost sosial, atau Peter $L$ Berger ${ }^{17}$ menyebut biaya sosial dengan istilah piramida pengorbanan. Bahkan nilai teknis (atau efektivitas dan efisiensi) merupakan satu indikasi dari pola hidup kemodernan, termasuk-menurut penulis - berpengaruh pula dalam kehidupan beragama. Agama yang memiliki birokrasi yang tidak efektif, dan tidak efisien terduga akan kurang diminati. Penulis sendiri, melihat fenomena keagamaan dalam Islam menampilkan sebuah gejala birokrasi yang pendek. Sebut saja misalnya untuk beribadah kepada Tuhannya. Seorang Muslim, tidak memerlukan perantara, atau rahib. Bahkan untuk yang terakhir itu adalah terlarang dalam hukum Islam. Itulah satu contoh yang penulis sebut "birokrasi keagamaan" yang efektif dan efisien. Dalam masalah bersuci, yang lumrahnya menggunakan air, ternyata dalam kondisi tertentu bisa dilakukan dengan menggunakan debu, Tayyamumlah namanya. Pemberlakuan fiqh seperti ini adalah satu gejala yang penulis sebut mudahnya birokrasi beragama dalam Islam. Teknik masuk Islam, syarat wajibnya hanya satu, yaitu membaca Syahadat di depan orang yang dituakan (ulama). Itupun adalah beberapa contoh tentang birokrasi keagamaan yang pendek. Inilah yang

${ }^{16}$ QS. Al-Anbiya: $52-71$.

${ }^{17}$ Piramida Kurban Manusia (Pyramids of Sacrafice) LP3ES: Jakarta, 1983, penerjemah, A. Rahman Tolleng. 
penulis anggap sebagai implikasi positif dalam kehidupan sekarang ini. Khususnya dalam kondisi kehidupan kita di era modern sekarang ini.

Sisi lainnya, kita cermati pula ada dimensi akal lain yang biasa digunakan dalam epistemologi lbrahim ini. Akal ini, kita sebut dengan akal filosofis (atau juga metafisis). Kita lihat dulu datanya. Data ini, kita dapati pula ungkapan-ungkapan Ibrahim, misalnya "Aku tidak suka pada yang tenggelam". Ungkapan seperti inilah, yang penulis kategorikan sebagai akal-filosofis. Dari sini pula, dalam pemahaman penulis, epistemologi lbrahim ini mengan-dung juga akal filosofis. Bahkan, kalau kita cermati gaya kritisnya Ibrahim dalam berdakwah atau berdialog dengan Ayahnya ${ }^{18}$ atau dengan umatnya termasukjuga dengan raja Namrud, maka tidak berlebihan ${ }^{19}$ jika disebut bahwa lbrahim telah mengaplikasikan metode filsafat dalam mencari hakikat Tuhan atau hakikat kebenaran. Fenomena serupa itu, khususnya kasus QS An-'am misalnya, Hamka sendiri menyebutnya sebagai referensi dalam pengembangan filsafat spiritualisme. Apapun namanya, penulis tetap menyebutnya dengan itulah bukti bahwa lbrahim AS mengembangkan akal-filosofis (al-'aql alfalasifah, philoshopic-intelegention) dalam berdakwah atau dalam pencaharian nilainilai kebenaran.

Perkembangan akal filosofis ini, amat subur berkembang di kalangan pemikir muslim yang berhaluan sufistik (tasawuf). ${ }^{20}$ Sebut sajalah, misalnya, Jalalludin Rumi, Mohammad lqbal, adalah figur-igur masyhur yang memiliki karakter tersebut tadi. Ideide keagamaannya, mereka tuangkan dalam bentuk syair-syair yang bemuansa filsafat. ${ }^{21}$ Suhrawardi, Ibnu 'Arabi pun demikian adanya. Kalau kita ingin menganalisis ide-ide keagamaan Suhrawardi, misalnya tentang filsafat iluminasionisme, maka kita akan berhadapan dengan teks-teks yang bentuk sastra, apakah itu berbentuk puisi maupun prosa. Mantiqu'I Thoir, karya Fariduddin Attar, ${ }^{22}$ adalah karya sastra yang juga sarat dengan nilai-nilai filosofis. Nampaknya akal filosofis ini juga adalah dimensi lainnya yang perlu dikembangkan dalam mengetengahkan epistemologi lbrahim.

Dalam epistemologi Jbrahim ini, nilai estetis tidak ketinggalan untuk digunakan. Sebagai contohnya untuk menunjukkan bahwa hal ini digunakan dalam epistemologi Ibrahim, yaitu dalam kemampuan Ibrahim menggunakan pilihan kata dalam berdakwah. Hamka, dan juga Al-Maraghy amat terkesan oleh penggunaan kata-kata oleh Ibrahim dalam berdakwah, selain tepat sasaran, logis tapi juga dikategorikan sebagai bahasa yang santun. Kemampuan memilih kata itulah (diksi) yang penulis anggap sebagai bagian dalam akal-estetis Ibrahim dalam praktik berdakwah.

${ }^{18}$ QS. Maryam, 41 - 50.

${ }^{19}$ Dengan asumsi bahwa filsafat diartikan sebagai sebuah metode berfikir kritis, sistematis sampai pada akar-akar persoalannya dengan tujuan mencari kebenaran hakiki.

${ }^{20}$ Dapat dikaji lebih lanjut misalnya Tasawuf: dulu dan sekarang, Sayyed Hossen Nasr, Pustaka Firdaus: Jakarta, 1991, juga pasang SurutAliran Tasawuf, A.J. Abeey, Mizan: Bandung, 1985.

21 Tentang Ibnu 'Arabi, Suhrawardi dan lbnu Sina dapat dilihat dalam buku-buku berikut ini misalnya, Syaikh al-Irsyad Shyihabuddin Yahya As Shurawardi, "Hikayathikayat Mistis", Bandung: Mizan, 1992, "Suhrawardi dan Filsafat llluminasi, "Hosen Zein, Zaman: Bandung, 1998. "Tiga Pemikir Islam: lbnu sina, Suhrawardi, Ibnu Sina," Seyyed Hossen Nasr, Risalah: Bandung, 1986.

${ }^{22}$ Lihat pendapat Hartijo Andangdjaja yang menerjemahkan Mantiqu'l Thoir "Musyawarah Burung". Pustaka Jaya: Jakarta, 1983: 5 


\section{Penutup}

Uraian di atas penulis anggap belum membahas secara utuh tentang epistemologi lbrahim ini. Hal ini penulis yakini benar. Oleh karena itu, uraian-uraian di atas dan juga pada bab-bab sebelumnya adalah bagian dari analisis eksploratif kita terhadap epistemologi lbrahim ini. Namun, karena itu pula, maka penulis perlu tegaskan bahwa inilah pengantar pemahaman penulis tentang epistemologi Ibrahim tersebut tadi.

Sebagai sebuah deskripsi penutupan, penulis ingin kemukakan bahwa Ibrahim As (atau Abraham) adalah figur yang dikenal oleh peradaban Barat dan (apalagi) juga Timur (Muslim). Oleh karena itu, ada hipotesis yang mungkin bisa diuji, yaitu paradigma sains dari ini adalah pemecahan dari paradigma berikimya Ibrahim. Atau kita sebut saja, epistemologi sains hari ini, adalah serbuk pecahan dari epistemologi lbrahim. Sebagaimana yang kita ulas di atas, bahwa akal telah mengalami pengikisan berulang-ulang, sehingga menjadi akal terbagi-bagi. Bahkan, akal (daiam huruf a kecil) telah termarjinalkan dari Akal (dalam huruf $A$ besar) yang seutuhnya. Kesadaran akan adanya pengeringan atau pengerdilan akal ini, banyak sudah kita temukan dalam referensi-referensi akademis di lingkungan masyarakat kita. Oleh karena itu, tidaklah heran jika generasi kita sekarang ini, telah diformat oleh akal yang termarjinalkan dari Akal, merasa asing bila berhadapan dengan akal yang "Berdimensi lain". Lebih ironisnya lagi, yaitu adanya sikap ketidakbersediaan kita untuk menerima keberadaannya akalakal tersebut tadi sebagai bagian dari keutuhan Akal kita. Sampai-sampai, misalnya, ilmu psikoanalisa dikategorikan oleh orang Barat sendiri sebagai jenis ilmu "pseudo science" (setengah ilmu). Dengan adanya kecurigaan-kecurigaan tersebut tadi, atau egoismenya-kebiasaan-keilmuan, maka lahirlah sikap sebagaimana yang ditulis oleh Kliping di atas, "Timur ya Timur, dan Barat ya Barat, dan keduanya tidak akan pernah bertemu". Sikap ini, bisa sah terjadi, jika kita memang tidak paham hakikat Akal itu dan eksistensi Akal tersebut tadi.

Pemikiran Kipling tersebut terfalu apriori bahkan skeptis akan ketidakmungkinannya bersatu antara Timur dan Barat. Bahkan ilmuwan politik modern pun, Samuel P. Huntingthon menyebutnya bahwa di abad XXI ini akan memasuki pada satu era pertentangan peradaban (clash of civilization). Benarkah dua peradaban tersebut akan bersifat saling menentang? Ternyata tidak semua sepakat terhadapnya. Misalnya saja, John L. Esposito, ${ }^{23}$ mengatakannya Islam bukan sebagai sebuah ancaman tetapi akan menjadi tantangan yang dinamis untuk menjadi solusi peradaban di masa yang akan datang. Dalam hal ini, penulis mengambil posisi optimis, bahwa kita perlu untuk melakukan rekonstruksi epistemologi. Dan inilah alasan utamanya, termasuk juga inilah sebagian acuannya. Untuk sisi optimistik tersebut itulah, maka poin-poin pemikiran tentang epistemologi lbrahim ini, kami kedepankan. Dengan begitu pula, penulis merasa tercapai target, jika ada pihak lain yang merasa perlu untuk mengkaji ulang tentang keabsahan analisis penulis pada epistemologi lbrahim tersebut tadi wallahu 'alam.

${ }^{23}$ Untuk bahasan ini, bisa dilihat misalnya pada buku "Ancaman Islam: Mitos atau Realitas". Mizan: Bandung, 1994, dan "Bahaya Hijau, kesalahpahaman Barat terhadap Islam", Pustaka Pelajar: Yogyakarta, 1997, karya John L. Esposito. 


\section{Daftar Pustaka}

Esposito. John L. 1997. Bahaya Hijau: Kesalahpahaman Barat Terhadap Islam. Yogyakarta:Pustaka Pelajar.

Garaudy,Roger.1986. Mencari Agama pada Abad XX: Wasiat Filsfat Roger Garaudy, Jakarta:Bulan Bintang.

Descartes, Rene.1995. Risalah Tentang Metode, Jakarta: Gramedia.

Wibisono, Koento. 1983. ArtiPerkem-bangan: Menurut Filsafat Positivistik August Comte, Yogyakarta: UGM Press.

Soewandi,Herman. 1996. Nalar, Kontemplasi dan Realitas, Bandung: Mizan.

Roesjen.S.1957. Irrasionalisme, Jakarta: BPK.

Al Qur'anul Karim, 2000. Jakarta:Depag

Sharif.M.M., 1970, Dialektika Islam: Alam Pikiran Islam. Bandung:Dipenegoro.

Tolleng,A. Rahman (Penerjemah).1983. Piramida Kurban Manusia (Pyramids of Sacrafice) Jakarta:LP3ES.
Nasr,Sayyed Hossen.1991.Tasawuf: Dulu dan Sekarang,Jakarta: Pustaka Firdaus.

Arbeey.A.J.1985, Pasang Surut Aliran Tasawuf,Bandung: Mizan.

Shurawardi,Syaikh al-Irsyad Shyihabuddin Yahya As.1992. Hikayat-hikayat Mistis, Bandung: Mizan,

Zein,Hosen. 1998.Suhrawardi dan Filsafat Illuminasi,Bandung: Zaman.

Nasr, Seyyed Hossen.1986. Tiga Pemikir Islam: Ibnu sina, Suhrawardi, Ibnu Sina, Bandung:Risalah.

Andangdjaja,Hartijo (Penejjemah) Mantiqu'l Thoir, 1983. "Musyawarah Burung". Jakarta:Pustaka Jaya.

Esposito,John L. 1994. Ancaman Islam: Mitos atau Realitas. Bandung: Mizan

Esposito,John L. 1997. Bahaya Hijau, Kesalahpahaman Barat terhadap /slam, Yogyakarta: Pustaka Pelajar. 